\title{
Co-expression of IGFs and GH receptors (GHRs) in gilthead sea bream (Sparus aurata L.): sequence analysis of the GHR-flanking region
}

\author{
Alfonso Saera-Vila, Josep Alvar Calduch-Giner and Jaume Pérez-Sánchez \\ Instituto de Acuicultura de Torre la Sal (CSIC), Fish Nutrition and Growth Endocrinology, Ribera de Cabanes, 12595 Castellón, Spain \\ (Requests for offprints should be addressed to J Pérez-Sánchez; Email: jperez@iats.csic.es)
}

\begin{abstract}
The tissue-specific expression of IGFs and GH receptors (GHRs) was analyzed in gilthead sea bream (Sparus aurata L.) as an attempt to understand the functional partitioning of duplicated GHRs on the regulation offish growth by season and aging. Gene transcripts were measured in liver, muscle, and adipose tissue by means of quantitative real-time PCR assays. In juvenile fish, concurrent increases in circulating levels of $\mathrm{GH}$ and IGF-I and hepatic mRNA levels of IGF-I and GHR-I were evidenced with the summer growth spurt. Conversely, muscle and adipose tissue expression of GHR-I and IGF-II were significantly upregulated by overwintering. The aging decrease of growth rates was accompanied by a reduced activity of the liver GH/IGF axis, and parallel increases in muscle IGF expression would be dictated at the local tissue level by the enhanced expression of GHR-I. Extra-hepatic expression of
\end{abstract}

IGFs and GHR-II did not correlate seasonally in juvenile fish, and nonsignificant effects of aging were found on the summer expression of GHR-II in any analyzed tissue. One transcription start site was identified by RLM-RACE in GHR-I and GHRII. Sequence analyses indicated that both genes have TATA-less promoters containing consensus initiator sequences and downstream promoter elements surrounding the transcription start site. Conserved CCAAT-boxes and GC-rich regions were retrieved in the GHR-I promoter, whereas stress- and redoxsequence elements (cAMP-responsive element-binding protein, activator proteins; AP-1, and AP-4) were characteristic features of GHR-II. All this supports the functional partitioning of fish GHRs regardless of fish species differences.

Journal of Endocrinology (2007) 194, 361-372

\section{Introduction}

Biological actions of growth hormone $(\mathrm{GH})$ are initiated by binding to specific receptors (GH receptors; GHRs) localized on the cell surface membrane of central and peripheral target tissues. These GHRs belong to the hematopoietic receptor superfamily, which includes among others receptors for prolactin (PRL), leptin, erythropoietin, granulocyte-stimulating factor, and interleukins (Kelly et al. 1991, Kopchick \& Andry 2000). Common characteristics are a single transmembrane domain, one or two pairs of positionally conserved cysteines, two regions of homology to the type III module of fibronectin, a WSXWS motif that is conserved as YXXFS in the mammalian GHR, and proline-rich Box 1 and Box 2 that are important for signal transduction (Kopchick \& Andry 2000). As a characteristic feature, expression of GHRs takes place at varying tissue levels, and the use of alternate promoters plays a major role in orchestrating a tissue-specific pattern. Heterogeneity in the $5^{\prime}$-untranslated region is in fact a well-documented phenomenon, and at least eight GHR mRNA variants splicing just upstream of the translation start site in exon 2 are reported for the human GHRs
(Goodyer et al. 2001, Orlovskii et al. 2004, Wei et al. 2006).

Fish GHRs were first cloned and sequenced in turbot (Scophthalmus maximus; Calduch-Giner et al. 2001) and goldfish (Carassius auratus; Lee et al. 2001). Later on the GHR cDNA sequences of many species including gilthead sea bream (Sparus aurata; Calduch-Giner et al. 2003), black sea bream (Acanthopagrus schlegeli; Tse et al. 2003), Japanese flounder (Paralichthys olivaceus; Nakao et al. 2004), common carp (Cyprinus carpio; GenBank accession number AY691176), grass carp (Ctenopharyngodon idella; AY283778), channel catfish (Ictalurus punctatus; DQ103502), Mozambique tilapia (Oreochromis mossambicus; Kajimura et al. 2004), coho salmon (Oncorhynchus kisutch; AF403539, AF403540), masu salmon (Oncorhynchus masou; Fukada et al. 2004), rainbow trout (Onchorhynchus mykiss; Very et al. 2005), Atlantic salmon (Salmo salar; Benedet et al. 2005), and Japanese eel (Anguilla japonica; Ozaki et al. 2006) have been reported. Most of these GHRs share several common features, and amino acid alignments reveal a relative high degree of identity (35-40\%) among GHRs of tetrapods and non-salmonid fish. Nevertheless, amino acid identity among GHRs of tetrapods and salmonids decreases up to $27-34 \%$ with a lack of three conserved cytoplasmatic tyrosine residues and two 
extracellular cysteines involved in a short disulphide link. Initially, fish GHRs were clustered in two clades: the first one corresponded to GHRs thus far described in non-salmonid fish (GHR type I) and the other clade encompassed most GHR sequences described in salmonid fish (GHR type II). This observation led to the suggestion that two different lineages of GHRs are present in teleost evolution. This assumption has now changed by the finding of two genomic contigs with a strict conservation of intron-exon junctions in fugu (Fugu rubripes), zebrafish (Danio rerio), and the Mediterranean gilthead sea bream (Saera-Vila et al. 2005). In the same study, the coexistence of duplicated GHR genes was experimentally supported in rainbow trout and European sea bass (Dicentrarchus labrax). Likewise, Jiao et al. (2006) cloned and sequenced the GHR-II in black sea bream, Southern catfish (Silurus meridionalis), and Nile tilapia (Oreochromis niloticus), providing further evidence for the coexistence of two GHR genes in a single fish species.

It is believed that duplication of genes and entire genomes are important mechanisms for morphological and functional innovation in evolution. At this standpoint, polyploidy has long been recognized in fish (Zhou et al. 2001, Volff 2005), and duplication and divergence offish GHRs would take place on an early ancestor of fish lineage. Salmonids are, however, considered recent tetraploids, and two isoforms of GHR-II are differentially expressed in rainbow trout (Very et al. 2005, Gabillard et al. 2006). Truncated variants of GHR-I have been characterized in turbot (Calduch-Giner et al. 2001) and Japanese flounder (Nakao et al. 2004), and this fact might allow the silencing and/or apparent genomic loss of GHR-II in the flatfish lineage (Saera-Vila et al. 2005). These truncated variants of fish GHRs comprise extracellular and transmembrane domains, the first 28 amino acid residues of the intracellular domain and a divergence sequence of 21-26 amino acid residues, which is the result of the lack of the alternative splicing of intron 9/10 (see Pérez-Sánchez et al. 2002).

Cloned GHR-I and GHR-II have shown to be functional in goldfish (Lee et al. 2001), black sea bream (Tse et al. 2003, Jiao et al. 2006), and Atlantic salmon (Benedet et al. 2005). In these studies, mammalian CHO-K1 were transfected with GHR cDNA and $\mathrm{GH}$ exposure triggers a strong proliferation response, which can also be induced by PRL at supraphysiological doses. Binding studies in masu salmon evidenced that GH and somatolactin (SL) may functionally interact through GHR-I (Fukada et al. 2005). Experimental evidence also indicates that the expression of GHR-II is modulated by water temperature in rainbow trout (Gabillard et al. 2006), whereas GHR-I and GHR-II are differentially regulated by cortisol and testosterone in black sea bream (Jiao et al. 2006). Previous studies in gilthead sea bream also revealed that duplicated GHRs are differentially regulated by fasting (Saera-Vila et al. 2005), although the relative contribution of each gene in the regulation of fish growth still remains unclear. Thus, the major goal of the present study was to analyze the tissue-specific expression of gilthead sea bream GHRs and insulin-like growth factors (IGFs) in relation with changes in growth (season and age models).
Additionally, transcription start sites and GHR-flanking regions were mapped as a first attempt to characterize GHR promoters in fish.

\section{Materials and Methods}

\section{Fish rearing and sampling}

Juvenile fish of 20-25 g initial body weight (8 months old) were reared until marketable size in triplicate 25001 tanks at the indoor experimental facilities of Instituto de Acuicultura de Torre de la Sal. Photoperiod and water temperature followed natural changes, and fish were fed with a commercial fish meal-based diet (Proaqua, Palencia, Spain) containing $47 \%$ protein and $21 \%$ lipid. Feed was adjusted to maximize growth rates and feed conversion efficiency through the entire productive cycle as described elsewhere (Mingarro et al. 2002). Specific growth rates (SGRs) were calculated monthly $(\mathrm{SGR}=(\ln$ final $\mathrm{wt}-\ln$ initial $\mathrm{wt}) \times 100 /$ days $)$. At critical step windows over the course of year (October, January, May, and July), overnight fasted fish were randomly selected (five fish per tank) and killed by a blow on the head under anesthesia (3-aminobenzoic acid ethyl ester, $100 \mathrm{mg} / \mathrm{l}$ ). Blood was taken from caudal vessels with heparinized syringes, and the resulting plasma samples $(3000 \mathrm{~g}$ for $20 \mathrm{~min}$ at $4{ }^{\circ} \mathrm{C}$ ) were stored at $-30^{\circ} \mathrm{C}$ until hormone assays. Liver, mesenteric adipose tissue, and dorsal skeletal muscle (white muscle) were rapidly excised, frozen in liquid nitrogen, and stored at $-80^{\circ} \mathrm{C}$ until RNA extraction and analysis.

Gilthead sea bream is a protandrous fish and 1-year-old (immature males), 2-year-old (mature males), and 3-year-old (mature females) fish were reared in triplicate groups as a second experimental set in 25001 tanks. Fish were fed with fish meal-based diets under standardized conditions, and randomly selected fish (5 fish per tank and 15 fish per group of age) were taken for blood and tissue collection during the summer growth spurt (July).

\section{Hormone assays}

Plasma GH levels were determined by a homologous gilthead sea bream RIA as reported elsewhere (Martínez-Barberá et al. 1995). The sensitivity and midrange (ED50) of the assay were $0 \cdot 15$ and $1 \cdot 8 \mathrm{ng} / \mathrm{ml}$ respectively.

Circulating levels of IGF-I were measured by means of a generic fish IGF-I RIA validated for Mediterranean perciform fish (Vega-Rubín de Celis et al. 2004a). The assay is based on the use of red sea bream (Pagrus major) IGF-I (GroPep, Adelaide, Australia) as tracer and standard, and anti-barramundi (Lates calcarifer) IGF-I serum (GroPep; 1:8000) as a first antibody. The sensitivity and midrange of the assay were 0.05 and $0.7-0.8 \mathrm{ng} / \mathrm{ml}$ respectively. 


\section{$R N A / D N A$ extraction}

Total RNA was extracted by the acid guanidium thiocyanatephenol-chloroform method (Chomczynski \& Sacchi 1987). Genomic DNA was isolated from blood with the High Pure PCR Template Preparation Kit (Roche) according to the manufacturer's instructions. Quantity and purity of RNA and DNA samples were determined by absorbance measures at 260 and $280 \mathrm{~nm}$ respectively. The integrity of isolated nucleic acids was tested by electrophoresis in agarose gels.

\section{Gene expression}

Transcripts of GHRs, IGFs, and $\beta$-actin were quantified in liver, adipose tissue, and muscle by means of real-time quantitative PCR assays. Briefly, after DNase I treatment, $2 \mu \mathrm{g}$ total RNA were reverse transcribed with 200 U Superscript II (Invitrogen: Life Technologies) using oligo $(\mathrm{dT})_{17}$ as anchor primer. Specific primers for GHR-I, GHR-II, IGF-I, and $\beta$-actin amplification were made as described elsewhere (Calduch-Giner et al. 2003, Saera-Vila et al. 2005). Primers for IGF-II (forward: TGGGATCGTAGAGGAGTGTTGT; reverse: CTGTAGAGAGGTGGCCGACA) were designed to amplify a $109 \mathrm{bp}$ amplicon, comprised between 392 and 500 nt positions (Duguay et al. 1996).

The iCycler iQ Real Time PCR Detection System (BioRad Laboratories Inc.) was used for sample cDNA quantification. Each reaction contained a SYBR Green Master Mix (Bio-Rad) and specific primers at a final concentration of $0.9 \mu \mathrm{M}$. The PCR protocol was $10 \mathrm{~min}$ at $95^{\circ} \mathrm{C}$ followed by 40 cycles of $15 \mathrm{~s}$ at $95^{\circ} \mathrm{C}$ and $60 \mathrm{~s}$ at $60^{\circ} \mathrm{C}$. Standard curves were generated by amplification of serial dilutions of known quantities of recombinant plasmids. For target and reference genes, the efficiency of PCR amplification was 94-96\% for serial dilutions of standards and RT reactions. Specificity of reaction was verified by the analysis of melting curves and by electrophoresis and sequencing of PCR amplified products. Reactions were performed in triplicate and fluorescence data were analyzed by interpolation of the cycle threshold $(\mathrm{Ct})$ value. Each transcript level was normalized to $\beta$-actin using the delta-delta method (Livak \& Schmittgen 2001). Tissue-specific levels of $\beta$-actin mRNA did not vary with experimental variables.

\section{Transcription start site}

Mapping of the transcription start site was made with the RLMRACE kit (Ambion, Austin, TX, USA) with minor modifications. Briefly, $1 \mu \mathrm{g}$ total RNA was dephosphorylated with calf intestinal phosphatase at $37^{\circ} \mathrm{C}$ for $1 \mathrm{~h}$. The mRNA cap structure was removed, and the purified mRNA was ligated with T4 ligase to an adapter oligonucleotide sequence. The ligation product was reverse transcribed with random decamers and Moloney murine leukemia virus (M-MLV) reverse transcriptase. PCR amplification was performed with an external primer and specific reverse primers for GHR-I
(CCTGGACTCCACCAACATCGGAATG; 362-338 nt position, GeneBank AF438176) and GHR-II (CGAGCGGAGCTGGACTTTGTAAG; 526-504 nt position, GeneBank AY573601). The nested PCR was conducted with a $5^{\prime} \mathrm{RACE}$ inner primer and specific reverse primers for GHR-I (GGAAACCAGGAGAAGGAGCAGGAGATTG; 228-201 nt position) and GHR-II (GGCTTGGAGAGGTTCTGGAGAGTG, 366-343 nt position). Conditions for PCR amplification were $2 \mathrm{~min}$ at $94{ }^{\circ} \mathrm{C}$ followed by 35 cycles of $30 \mathrm{~s}$ at $94{ }^{\circ} \mathrm{C}, 30 \mathrm{~s}$ at $60^{\circ} \mathrm{C}$, and $30 \mathrm{~s}$ at $72^{\circ} \mathrm{C}$ with a final extension of $15 \mathrm{~min}$ at $72^{\circ} \mathrm{C}$. The amplified PCR products were gel extracted (QIAquick gel extraction, Qiagen) and sequenced by the deoxy chain termination method (ABI PRISM dRhodamine terminator cycle sequencing kit, Perkin-Elmer, Wellesley, MA, USA).

\section{Analysis of GHR-flanking region}

Genomic DNA was used for the construction of Genome Walker libraries by means of the Universal GenomeWalker kit (BD Biosciences, Bedford, UK). Briefly, 2.5 $\mu \mathrm{g}$ aliquots of genomic DNA were digested with DraI, EcoRV, and PvuII respectively. Digested DNAs were extracted, precipitated, and synthetic adapters were ligated to genomic DNA fragments using T4 DNA ligase. Two reverse primers surrounding the transcription start site of GHR-I (TGGTACGAAGTCTCGAGGTGGTG and TTTCACAACTTGGTCATCTGATGGC) and GHR-II (TGAGAACCACACAG AAAC TGTTCAACC and CTCCATGTAAGCTGGTGACGCTG) were designed to be used with adapter primers in primary and secondary PCRs $\left(35\right.$ cycles for $30 \mathrm{~s}$ at $94^{\circ} \mathrm{C}, 30 \mathrm{~s}$ at $57{ }^{\circ} \mathrm{C}$, and $300 \mathrm{~s}$ at $72^{\circ} \mathrm{C}$ ). PCR-amplified fragments were purified and sequenced as described earlier.

Bioinformatics analyses of regulatory elements were performed with the MatInspector software (http://www. genomatix.de). A preliminary analysis was made with a core similarity of 0.75 and an optimized matrix similarity value to allow the recovery of a comprehensive list of candidate factors. To discard false positives, MatInspector was rerun with a core similarity threshold and a matrix similarity value of 1 and 0.90 respectively.

\section{Statistical analysis}

Data were analyzed by Student's $t$-test and one-way ANOVA followed by Student-Newman-Keuls test $(P<0 \cdot 05)$. Correlation analyses were made by Pearson product moment correlations.

\section{Results}

\section{Seasonal trial}

In juvenile fish, circulating levels of GH and IGF-I varied together $(r=0 \cdot 68, P<0 \cdot 001)$, following seasonal changes in 
growth rates and environmental cues. Thus, the growth spurt of summer occurred in coincidence with the highest circulating concentration of GH and IGF-I (Fig. 1).

Hepatic transcripts of GHR-I increased with the rise of growth rates and the maximum gene expression was attained in July (Fig. 2A). By contrast, in adipose tissue (Fig. 2B) and muscle (Fig. 2C), the highest amount of GHR-I transcripts was found in January. The liver transcriptional profile of GHR-II paralleled that reported for GHR-I $(r=0 \cdot 711$, $P<0 \cdot 001$; Fig. 2D). However, a different tissue regulation was found in peripheral tissues, and adipose tissue transcripts of GHR-II peaked in July (Fig. 2E), whereas muscle expression remained high from January to July (Fig. 2F).

In liver, the highest amount of IGF-I mRNA levels was attained in July (Fig. 3A), and a close positive correlation was found with circulating levels of IGF-I over season $(r=0 \cdot 77$, $P<0 \cdot 001)$. Hepatic transcripts of IGF-I were also positively correlated with hepatic mRNA levels of GHR-I $(r=0 \cdot 703$, $P<0 \cdot 05)$ and GHR-II $(r=0.804, P<0 \cdot 001)$. Muscle and adipose tissue expression of IGF-I was 20 - to 100 -fold lower than in liver, and nonsignificant changes over the course of season were detected in these extra-hepatic tissues (Fig. 3B and C).

Seasonal changes in hepatic IGF-II gene expression were not found in juvenile fish (Fig. 3D). Extra-hepatic expression of IGF-II remained relatively high, and a maximum for IGFII transcripts was found in January (Fig. 3E and F). Thus, a positive correlation between IGF-II and GHR-I transcripts was reported in adipose tissue $(r=0.528, P<0.05)$ and muscle $(r=0 \cdot 479, P<0 \cdot 05)$.

\section{Age trial}

In summer, growth rates and circulating levels of GH and IGF-I decreased progressively and significantly with advancing age in 1-, 2- and 3-year-old fish (Fig. 4). Older fish also showed a decreased hepatic expression of GHR-I (Fig. 5A), whereas the amount of these transcripts did not vary significantly in adipose tissue (Fig. 5B). By contrast, muscle expression of GHR-I was significantly increased in older fish (Fig. 5C). Significant agerelated changes in the expression of GHR-II were not found in any examined tissue (Fig. 5D-F).

The age-related changes in IGF-I and IGF-II transcripts followed similar trends (Fig. 6). However, the range of individual variation was higher for IGF-II, and nonsignificant changes in IGF-II expression were detected in any analyzed tissue. By contrast, hepatic expression of IGF-I decreased significantly in older fish (Fig. 6A). This trend was opposite to that found in skeletal muscle (Fig. 6C), and a positive correlation between GHR-I and IGF-I transcripts was reported in liver $(r=0 \cdot 682, P<0 \cdot 05)$ and muscle $(r=0 \cdot 626, P<0 \cdot 05)$.

\section{Alternative splicing and sequence analysis}

Two bands of 500 and 400 bp were obtained by RLM-RACE of GHR-I and GHR-II respectively. The reliability of this
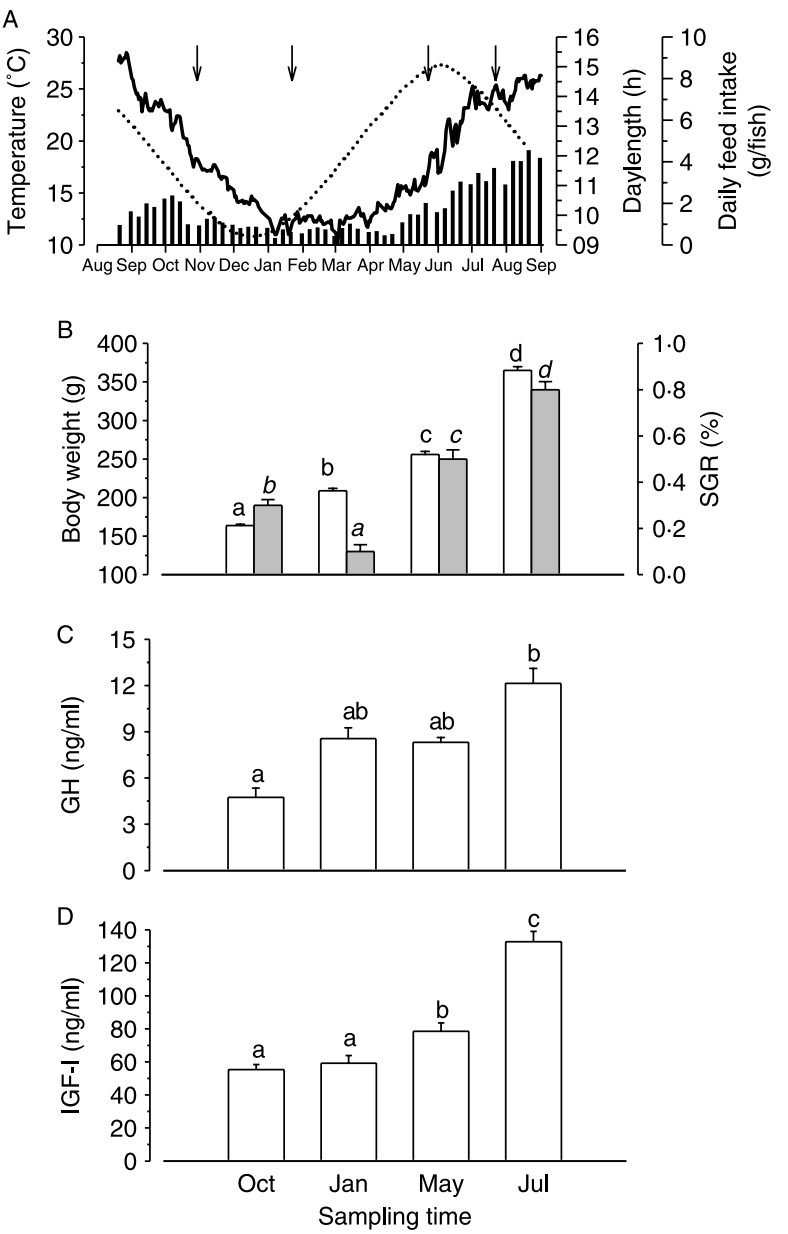

Figure 1 Seasonal changes in water temperature (continuous line), daylength (dotted line), and daily feed intake of growing juvenile fish (bars); arrows indicate sampling times for blood and tissue collection (A). Body weight (white bars) and specific growth rates (gray bars) at sampling times (B). Plasma levels of $\mathrm{GH}$ (C) and IGF-I (D). Growth parameters are the average values (mean \pm s.E.M.) of triplicates tanks. Hormone data are the mean of ten fish. Different letters above each bar indicate statistically significant differences between sampling times $(P<0 \cdot 05$, Student-Newman-Keuls).

finding was checked by PCR, and the results allow us to determinate two transcription start sites (one for each gene) delimiting the $5^{\prime}$-flanking region of exon 1 . This exon codes entirely for the $5^{\prime}$-UTR sequence, which was verified by the screening of Genome Walker libraries of GHR-I (Fig. 7A) and GHR-II (Fig. 7B). Exon 1 of GHR-I was located $9 \mathrm{~kb}$ upstream of exon 2 as further demonstrated by long PCRs with intact genomic DNA and specific primers surrounding flanking regions of exon 1 (forward primer, GCTCTCACGCTGGCCATCAGATGAC) and exon 2 (reverse primer, GGCTGTCAGAATTCCTACACAGGTAG). A similar strategy was used for GHR-II but no positive results were obtained, which suggests a long intron 1 that may be difficult to amplify by PCR. 

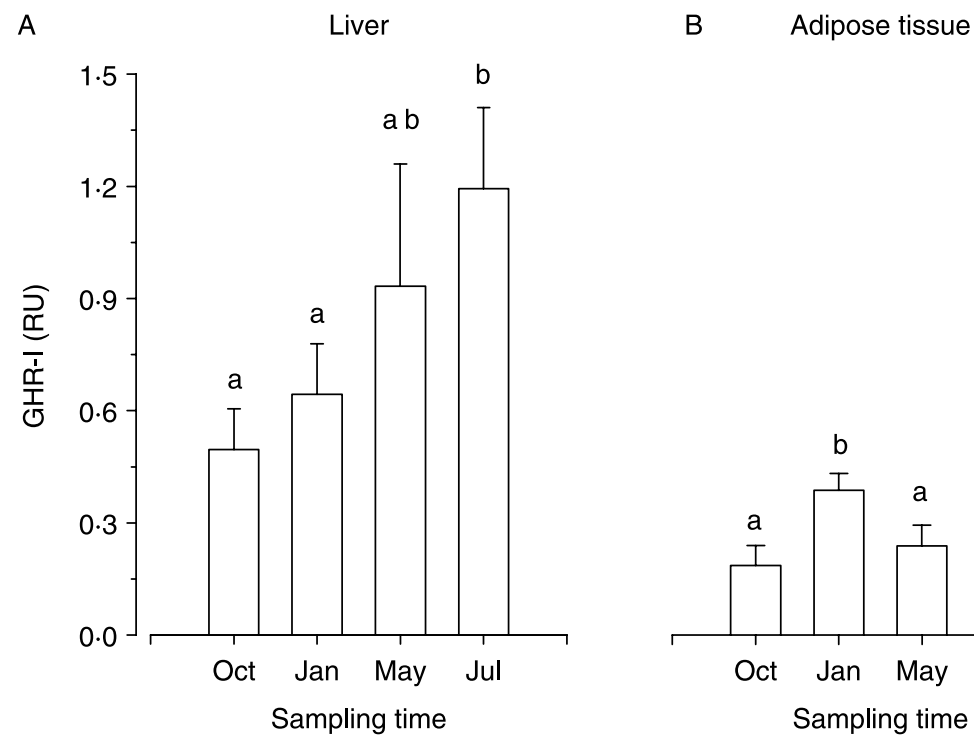

C

Muscle
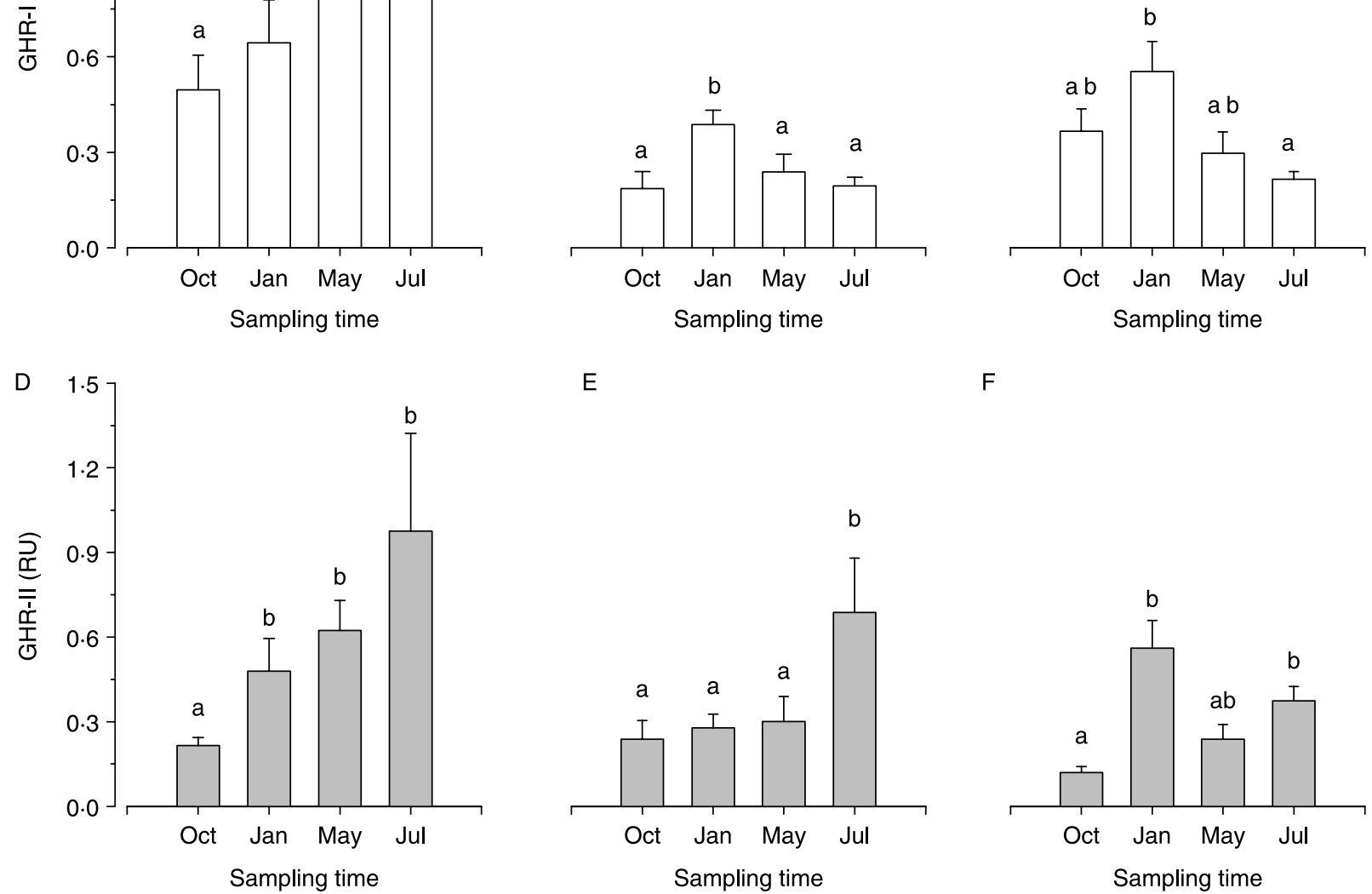

Figure 2 Seasonal changes in the tissue-specific expression (relative units) of GHR-I and GHR-II. For each gene, the highest expression among tissues was used as reference value in the normalization procedure. Data are the mean \pm S.E.M $(n=6)$. For each tissue, different letters above each bar indicate statistically significant differences between sampling times $(P<0 \cdot 05$, Student-Newman-Keuls).

Sequence analysis of the $5^{\prime}$-flanking region of GHR-I (1589 pb; GeneBank accession number AH014067) and GHR-II (1262 pb; AH014068) did not reveal a consensus TATA-box surrounding the transcription start site. However, regulatory elements similar to the consensus for the initiator element (Inr) were retrieved in the promoter region of both genes. Also, sequences similar to downstream promoter element (DPE) were found at positions +38 (GHR-I) and +29 (GHR-II). CCAATboxes and GC-rich sequences were only retrieved in the proximal-flanking region of GHR-I (see Fig. 7A). Binding sites for cAMP-responsive element-binding protein (CREB) and activator proteins (AP-1 and AP-4) were exclusively found in the GHR-II-flanking region (see Fig. 7B).

\section{Discussion}

The use of alternate promoters orchestrates in mammals a tissue-specific pattern of GHR expression (Goodyer et al. 2001, Orlovskii et al. 2004). This schema is apparently simplified in fish, and only one transcription start site was evidenced herein in gilthead sea bream GHRs. However, genome duplication offers a second level of regulation, and two functional GHR genes (with additional isoforms in salmonids) have been conserved in several lineages of modern bony fish. These two GHRs span more than $20 \mathrm{~kb}$ in gilthead sea bream, and share a strict conservation of exon-intron junctions (see Pérez-Sánchez et al. 2002, Saera-Vila et al. 2005). In the present study, the gene organization was completed at the $5^{\prime}$-flanking region, and $1 \cdot 5-1 \cdot 2 \mathrm{~kb}$ just 

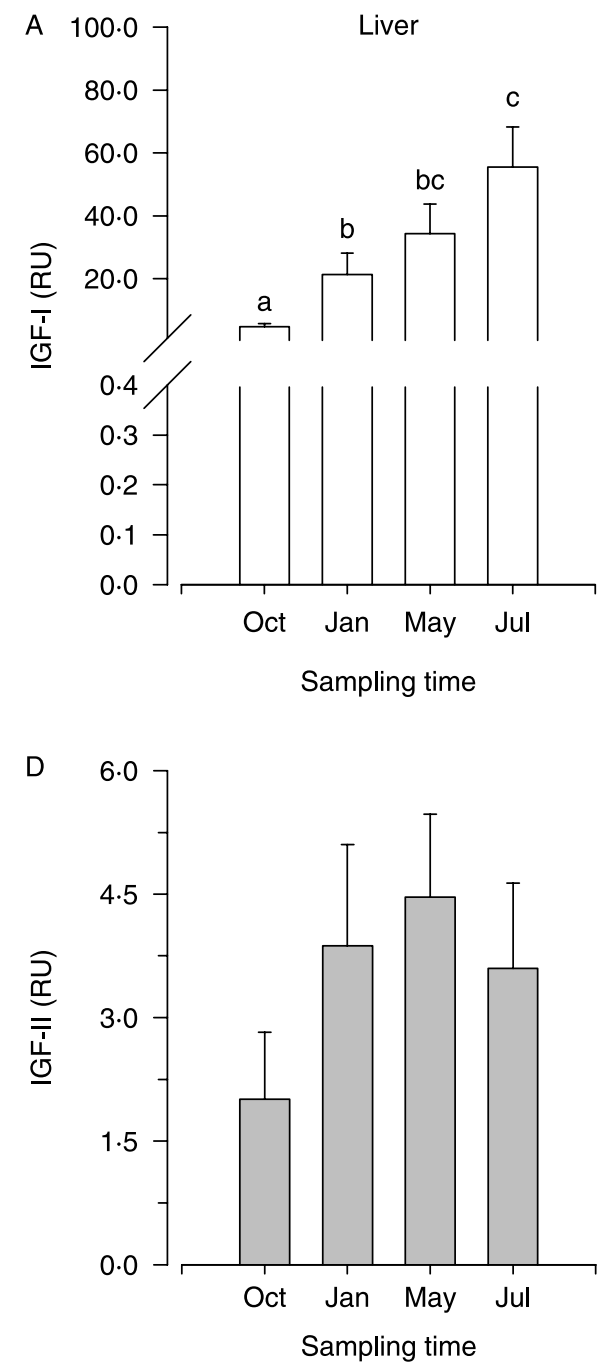

B

Adipose tissue

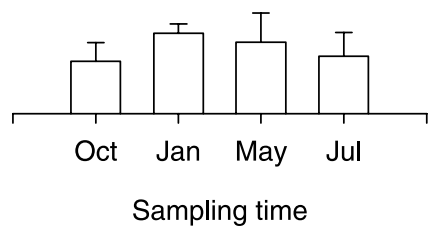

$\mathrm{E}$

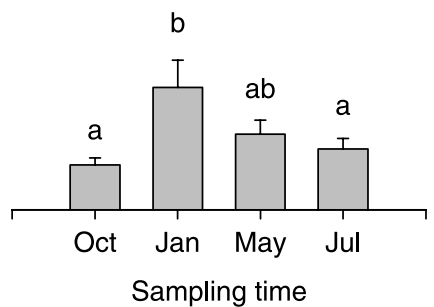

C Muscle

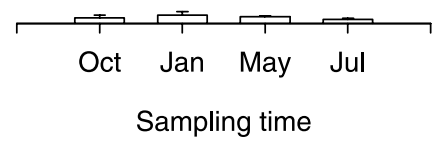

$\mathrm{F}$

Figure 3 Seasonal changes in the tissue-specific expression (relative units) of IGF-I and IGF-II. For each gene, the highest expression among tissues was used as reference value in the normalization procedure. Data are the mean \pm s.E.M $(n=6)$. For each tissue, different letters above each bar indicate statistically significant differences between sampling times $(P<0 \cdot 05$, Student-Newman-Keuls).

upstream of the transcription start site were sequenced in GHR-I and GHR-II respectively. This represents a first attempt to characterize the promoter region of fish GHRs, which may serve to better understand the complex regulatory processes driving the tissue-specific expression of IGFs in different growth and living conditions.

Both in mammals and fish, the liver is the most important target tissue of GH and the primary source of systemic IGF-I (endocrine form). Thus, plasma levels of IGF-I are a good indicator of growth rates in European sea bass (Vega-Rubín de Celis et al. 2004a) and channel catfish (Silverstein et al. 2000, Li et al. 2006). Circulating levels of IGF-I are positively correlated with growth rates and dietary protein levels in barramundi and Atlantic salmon (Dyer et al. 2004). In salmonids, the regulation of circulating IGF-I is well documented on the basis of seasonal and nutritional cues
(Dickhoff et al. 1997, Larsen et al. 2001, Nordgarden et al. 2005). In gilthead sea bream, circulating levels of IGF-I are higher than those reported in salmonids and also correlate with growth shifts, derived from changes in season (Mingarro et al. 2002) and nutritional condition (Gómez-Requeni et al. 2003, 2004, Benedito-Palos et al. 2007). In the present study, this notion was further supported by concurrent changes in growth rates, circulating levels of GH and IGF-I, and hepatic mRNA levels of IGF-I and GHR-I. Hence, systemic increases of IGF-I would be mostly mediated in season and aging by the hepatic transcriptional activation of GHR-I. Moreover, hepatic mRNA levels of GHR-II did not vary with aging, and GHR-II emerges in older fish as a ubiquitous gene that apparently did not mediate the age-related decrease in growth rates and hepatic IGF expression. Alternatively, GHR-II may be involved in tissue repair and survival, which 

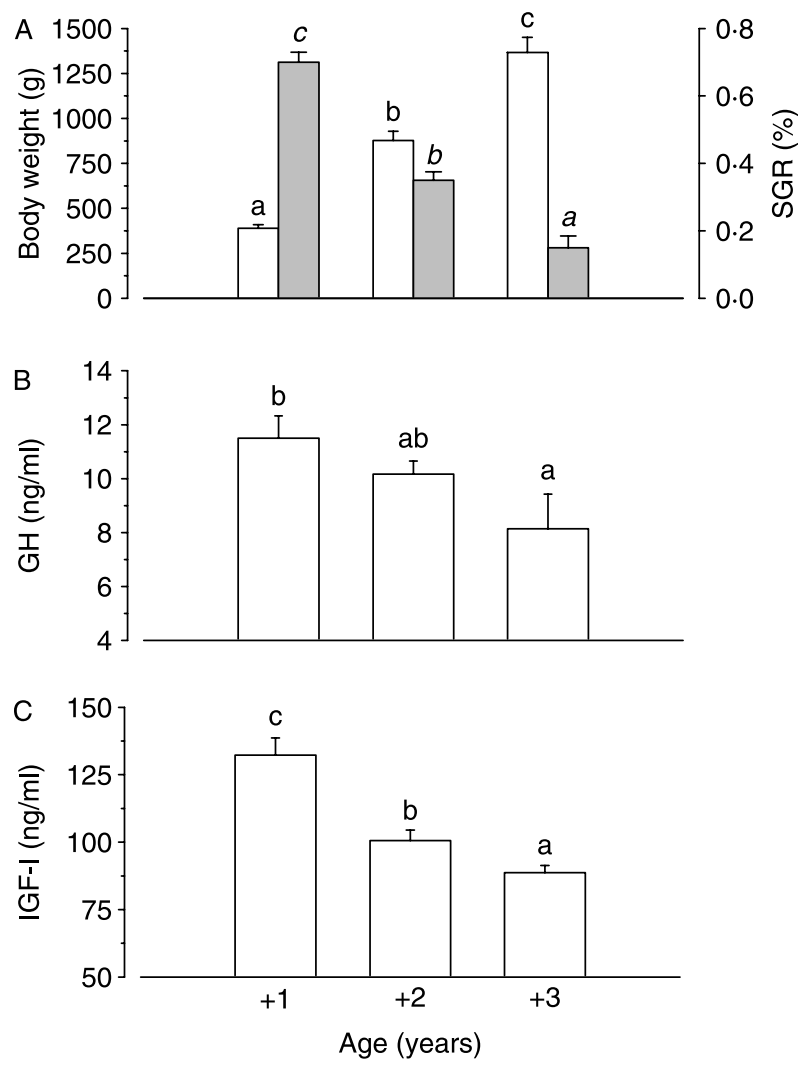

Figure 4 Summer age-related changes in body weight (white bars) and specific growth rates (gray bars) (A). Plasma levels of $\mathrm{GH}$ (B) and IGF-I (C). Growth parameters are the average values (mean \pm s.E.M.) of triplicates tanks. Hormone data are the mean of ten fish. Different letters above each bar indicate statistically significant differences between sampling times $(P<0 \cdot 05$, Student-Newman-Keuls).

would explain the reported upregulated expression of muscle GHR-II by fasting (Saera-Vila et al. 2005). Muscle disuse atrophy was also associated in rats to the enhanced expression of GHRs, although this attempt of muscle repair requires intact insulin and IGF-I receptor signaling (Casse et al. 2003, Kim et al. 2005).

Hepatic IGF-I is not crucial for postnatal growth in mice, and liver IGF-I knockouts show normal growth due to the compensatory action of autocrine/paracrine IGF-I (see Le Roith et al. 2001a,b). Postnatally elevated levels of IGFII fail to rescue the dwarfism of IGF-I-deficient mice (Moerth et al. 2007), although species-specific differences appear to be important in IGF-II expression and function. Thus, transcripts of IGF-II decrease quickly during the postnatal development of mice and rats (Rotwein 1991), but substantial amounts are found later in life in humans and in a wide range of fish species, including common carp (Vong et al. 2003), rainbow trout (Chauvigné et al. 2003), Nile tilapia (Caelers et al. 2004), channel catfish (Peterson et al. 2004), and gilthead sea bream (Duguay et al. 1996). Of note, a relative high expression of IGF-II is retained in extra-hepatic tissues of most fish species, and compensatory increases of muscle IGFII have been documented in fast-growing juveniles of gilthead sea bream when they were fed practical diets with increased amounts of feed-borne contaminants (Benedito-Palos et al. 2007). The muscle expression of GHR-I was not significantly altered by this dietary intervention, which agrees with the common notion that autocrine/paracrine IGF effects are mostly GH independent (Wood et al. 2005). However, in the present study, correlation analyses suggested that the increased muscle expression of IGF-II by overwintering would be mediated by the upregulated expression of GHR-I. Parallel increases of IGFs and GHR-I mRNA levels also occurred in the muscle tissue of older fish during the summer growth spurt. Hence, this locally enhanced expression of GHR-I may be considered adaptive to face up a reduced activity of the liver GH/IGF-I axis. However, the relative contribution of fish GHRs on growth and IGF regulation probably depends not only on fish lineage, but also on each particular age, nutritional, and environmental condition. Jiao et al. (2006) showed that duplicated GHR genes are differentially regulated by cortisol in black sea bream, a closely related sparid fish. In this regard, the evolutionary scenario for most paralog genes is consistent with the partitioning of ancestral functions after degenerative mutations in different regulatory and/or structural sequences (sub-functionalization model; see Volff 2005). The microphthalmia-associated transcription factor (MITF) is perhaps one of the most illustrative examples, mammals and birds having a unique MITF gene which generates different isoforms through the use of alternate promoters. By contrast, fish have two different MITF genes that are present in species as divergent as zebrafish, pufferfish, and platyfish.

The sub-functionalization model might also be applied to GHRs, which evolved in gilthead sea bream as duplicated genes with a single transcription start site. By contrast, GHRs of higher vertebrates have multiple untranslated exons that are alternatively spliced to a common acceptor site. These spliced transcripts are modulated by different regulatory elements, having liver-specific GHRs, a TATAbox surrounding the transcription start site (Goodyer et al. 2001). Other conserved and ubiquitous mammalian GHR variants have TATA-less promoters, and the transcription initiation is determined in the bovine $\mathrm{P} 1$ promoter by $\mathrm{Inr}$ substitutes (Jiang et al. 2000). Sequences similar to consensus Inr were also found herein, which indicate that transcription initiation of GHRs can be dictated in fish and higher vertebrates by Inr-like sequences that were initially subestimated in metazoan genomes (Gross \& Oelgeschläger 2006). Moreover, many core promoters contain downstream elements, and consensus sequences for the DPE appear to be essential for the activity of most Inr promoters (Smale 1997, Smale \& Kadonaga 2003). This may be the case of the two gilthead sea bream GHRs, which have retained Inr and DPEs surrounding the transcription start site.

Typically, TATA-less promoters have CCAAT-boxes in the forward or reverse orientation between -60 and -100 of the 

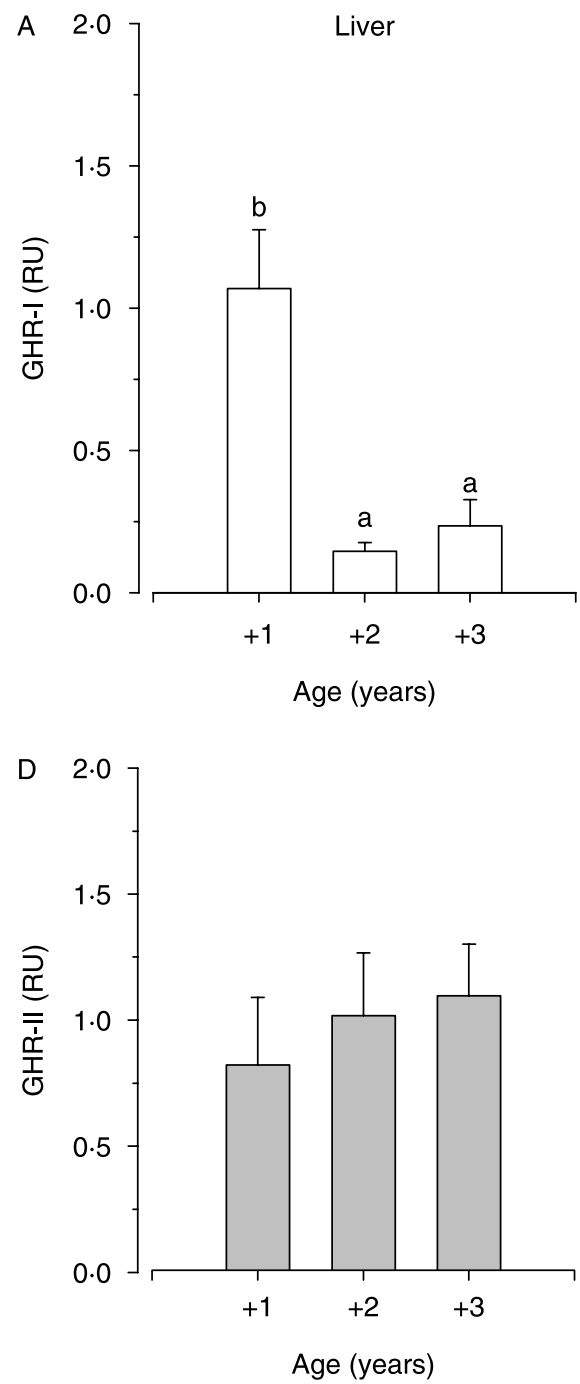

B

Adipose tissue

E

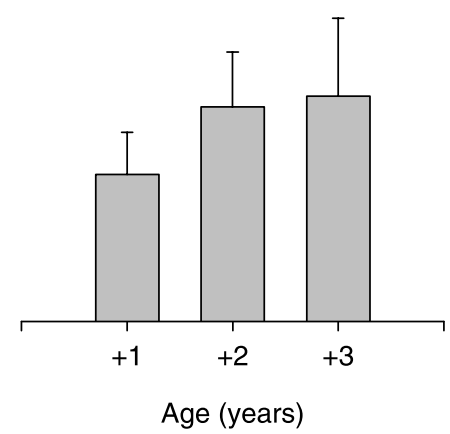

C

Muscle

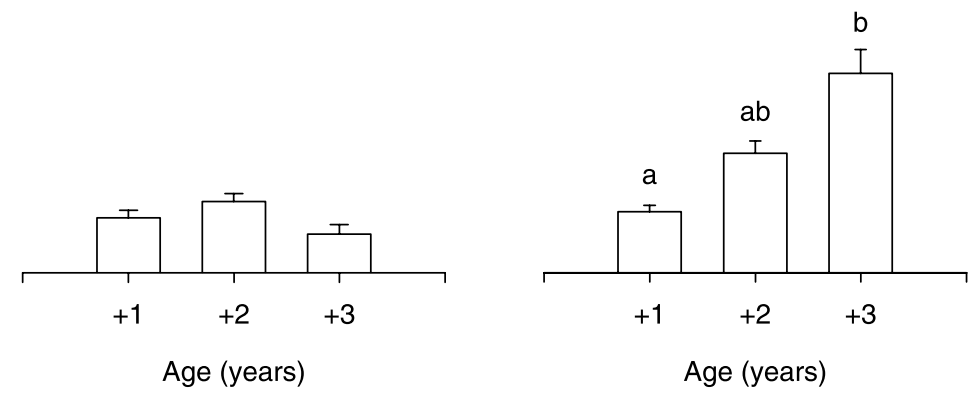

$\mathrm{F}$

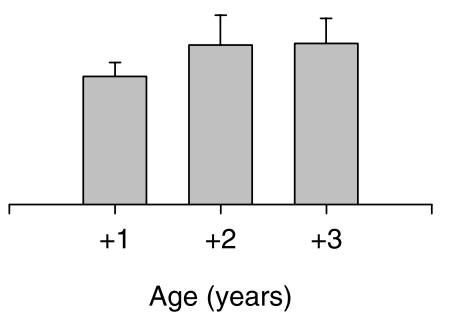

Figure 5 Summer age-related changes in the tissue-specific expression (relative units) of GHR-I and GHR-II. For each gene, the highest expression among tissues was used as reference value in the normalization procedure. Data are the mean \pm S.E.M $(n=6-7)$. For each graph, different letters above each bar indicate statistically significant differences between sampling times $(P<0 \cdot 05$, Student-Newman-Keuls).

major start site (Mantovani 1999). Consensus GC-boxes are also common elements in TATA-less promoters, and functional CCAAT-boxes and Sp1-binding sites have been identified in human $\mathrm{V} 2$, bovine $1 \mathrm{~B}$, ovine $1 \mathrm{~B}$, mouse $\mathrm{L} 2$, and rat GHR2 promoters (see Goodyer et al. 2001). Functional binding sites for the ubiquitous ZBP-89 have also been reported in the bovine GHR1A promoter (Xu et al. 2006). In this study, a conserved CCAAT-box and a GC-rich region (identified as a ZBP-89/Sp1-binding site) were retrieved in the GHR-I-flanking region of gilthead sea bream. Hence, structural, transcriptional, and regulatory features suggest that GHR-I of sparid fish evolved as a true orthologous gene of mammalian GHRs. Nevertheless, the regulation of duplicated fish GHRs is a complicated and intriguing process, and we cannot exclude some overlapping and functional redundancy of fish GHRs. Thus, ongoing studies indicate that the reduction of hepatic IGF expression during crowding stress might be dictated by GHR-II rather than GHR-I (unpublished results). Supporting this, CREB and AP-1 recognition sites were found in the GHR-II-flanking region of gilthead sea bream. The regulation of CREB (Hai \& Hartman 2001) and AP-1 (Prabhakar 2001, Kim et al. 2002) have been extensively studied in mammals, and serve as models of stress- and redox-sensitive transcription factors. Of note, AP-4 is a closely related transcription factor that is rapidly downregulated by glucocorticoids (Tsujimoto et al. 2005), and various AP-4 sequence elements were retrieved in the proximal $5^{\prime}$-flanking region of gilthead sea bream GHRII, although its functional relevance remains still to be demonstrated. 

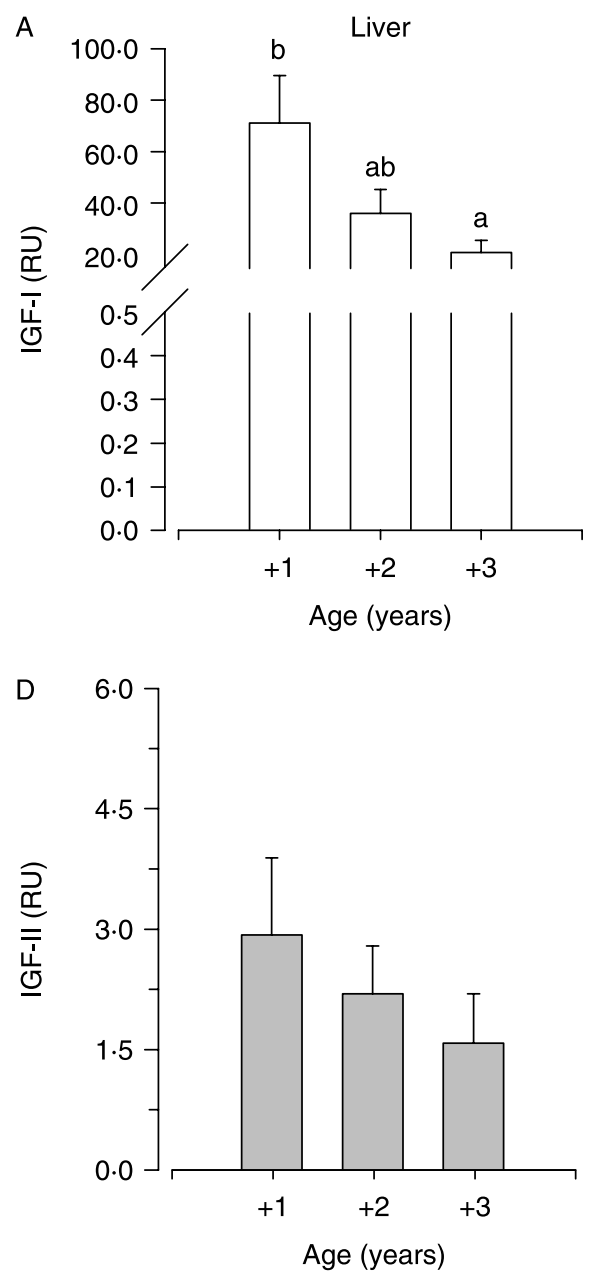

B

Adipose tissue

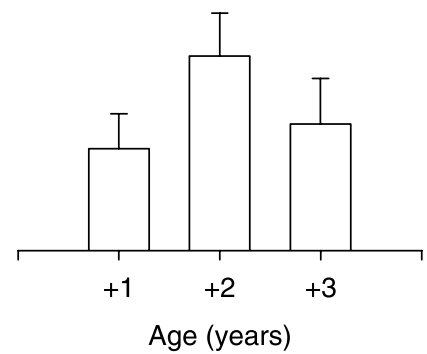

$\mathrm{E}$

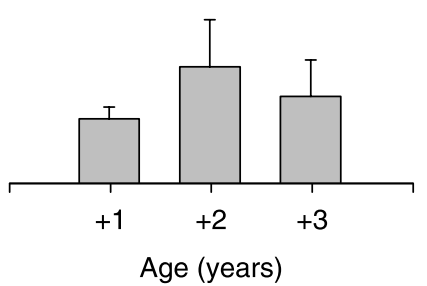

C

Muscle

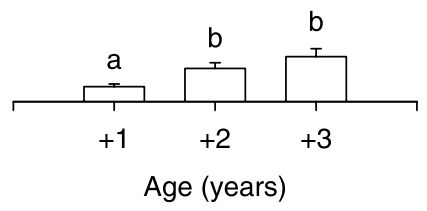

$\mathrm{F}$

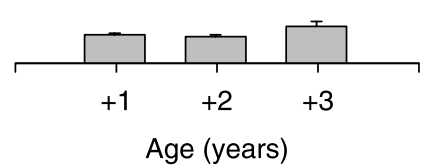

Figure 6 Summer age-related changes in the tissue-specific expression (relative units) of IGF-I and IGF-II. For each gene, the highest expression among tissues was used as reference value in the normalization procedure. Data are the mean \pm s.E.M $(n=6-7)$. For each tissue, different letters above each bar indicate statistically significant differences between sampling times $(P<0 \cdot 05$, Student-Newman-Keuls).

Experimental evidence shows that SL rather than GH binds to GHR-I of masu salmon (Fukada et al. 2005). Orthologous medaka genes could also mediate SL signaling (Fukamachi et al. 2005), but the switch and diversification of GHR functions are highly probable among fish lineages. Thus, the binding capabilities of GHRs have been characterized in Japanese eel, and the recombinant eel GHR-I binds specifically to $\mathrm{GH}$ and does not cross-react with eel SL (Ozaki et al. 2006). In the same context, GHR-II is apparently lost or silenced in turbot, and GHR-I and truncated isoforms emerge as the unique functional GHR in the flatfish lineage (see Saera-Vila et al. 2005). Regardless of this, each ligand/receptor interaction can result in unique signaling outcomes as was reported in mammals for insulin receptor and insulin/IGF ligands (Denley et al. 2005). Thus, recombinant SL does not exert a growth-promoting action in gilthead sea bream, but has a lipolytic action similar to that found with GH preparations, which was evidenced by changes in the respiratory quotient and activities of lipolytic enzymes (Vega-Rubín de Celis et al. 2003). Additionally, differences in binding affinities and ligand abilities may contribute to make a hypothetical scenario in which GH and SL work through a same receptor. Combined data on plasma GH and SL levels have not been included in this article, although previous studies clearly proved in gilthead sea bream a specific seasonal pattern for each GH/PRL family member (Mingarro et al. 2002, Pérez-Sánchez et al. 2002). Furthermore, opposite trends for circulating GH and SL have been reported with advancing age and changes in nutritional condition, arising from shifts in ration size, dietary composition, and secretagog effects of arginine (Company et al. 2001, Vega-Rubín de Celis et al. 2004b).

In summary, coexpression analyses suggest a key role of GHR-I in the tissue-specific regulation of IGFs in a nonsalmonid fish of economical relevance for the Mediterranean aquaculture. Some functional redundancy of GHR-I and 
A

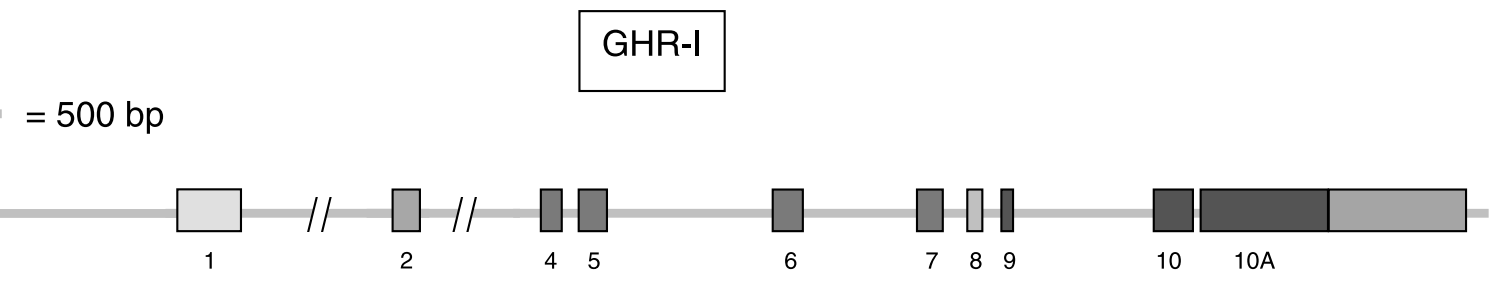

tctcagactcatcgctttaaatgtaaactatgcggttctaccccatgataaatagcccaataaatgat $\quad-190$ tattagacctcatttaaactttggctctcttcacagagcgtggcagctaccgggtggttttattttggaa $\quad-120$ gtttggcccggcagactctccccccctccccaacccccggcttgtcctcctctgtgtggccagaatggag $\quad-50$ cagattggattgctggcggatgagggcgcctcaccgccatttgaaacacACACGTACTGGCTCCGTCTCC 21

CCAAT $\frac{\text { Inr }}{\ln }$
GCTACGTAGCGTGTGTAGCCCCCTGAAAGTGAGCTTGGATGATGAGCTGAGCGACTAGACTAGACTGGAC DPE

CCACAATCTTGACAACAGGAAAGCGGCACGAACCСTTTTTTTTTTCTCCTCCCCTCAAATGATCCGGGTG ATGTGATAGAAGCCCCCCGATCGCAGAGATCACACCGGGGGCCGAGCGGGGGCTGAAGTGAAGACGCAGG АСTTTTTTTTGGTTTTGCTCTCACGCTGGCCATCAGATGACCAAGTTGTGAAAAGTCGGATCTGCGTTGC CCGTGCAGTTTTTTTTTCTTCTTTCTGTCTTCTTCCCCCACCACCTCGAGACTTCGTACCAACgtaagtg cgtttatgtgcttttaaacgtgcagtgcatcttttttaatggtgtgtgtgtgtgtgtgtgtgtgtgtg tgtgt...

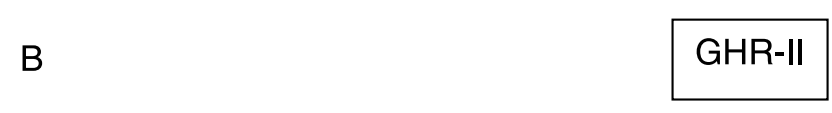

$=500 \mathrm{bp}$

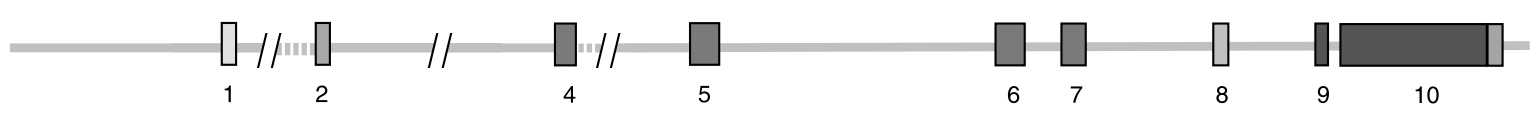

actaaaacactttttatatcagatactttgactcaattactatttgtacagaggcttttacatttag $\mathrm{AP}-1$

aaaagtacctttactcttactcaagtatgatttttgagtactttggcaacactgtcagtgttcctggaca

gctgcgggttgttttcctgctgtactcagactccaccgacagatggcgccattctctccgcctcagaacc

agccgggggactattacagctgtgctgctgctgctgctgctgctgctggtccacacacacactcacacac

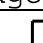
acACACTCACAGAGACCGTCAGCCAGGCAGGGTTTCTTCGACAGCGTCACCAGCTTACATGGAGCTCGGT $\frac{\text { Inr }}{\text { CREB }} \frac{\text { DPE }}{\text { CREB }}$ TGAACAGTTTCTGTGTGGTTCTCAGCGGGTATCTGCGGTCTGAACGCGGACTGTTAGAGTTTGTGTTGTT GCAGTTGGATGAGGGAGCGGAGCTGCAGACTGCTGTCCAGCGgtgagtgactctcatgtccgtgtgtgtg tgtgtgtgtgcacccagctgcatgtaaagccagggtgtctggcagctcctggttcaactcacggtctgag ccgtgttagacggaggctgtttacttcatgcctgtcttcgtgtcggagcctgttcgcggtttaattgagg tgctcttcacgagtcttgcacaatctcagagcgcacagaggaaaacagctctgagatcggaccgcagcgc tggaaaacaaacctcagacctcagtacactgatagagagagaaagttcatctacacttgtcctacaaaaa gttgtgacacaatgtgatagatacaccggtcaggtctacaggtggtggtgtattctcttcaattttgag agtacttcagaaaattaggcaattt...

Figure 7 Exon-intron organization and sequence analysis of the 5'-flanking region of GHR-I (AH014067) and GHR-II (AH014068). In both genes, exon 1 codes for $5^{\prime}$-UTR; exon 2 for signal peptide; exons 4-7 for extracellular domains; exon 8 for trans-membrane domain; exons 9 and 10 for intracellular domains; exon $10 \mathrm{~A}$ for intracellular and $3^{\prime}$-UTR domains. Exon 1 is in capital letters and splicing consensus is printed in bold. Transcription start sites of GHR-I and GHR-II are indicated by arrows. Consensus sequences (CCAAT, GC rich, AP-1, AP-4, CREB, Inr, and DPE) surrounding transcription start sites are underlined. 
GHR-II cannot be excluded, emerging GHR-II as a stressand redox-sensitive genes. This notion is supported by sequence analysis of the $5^{\prime}$-flanking region, although functional studies remain to be implemented to document the physiological relevance of consensus-binding sites in the core promoter of fish GHRs. Additionally, detailed studies merit to be conducted to explore and better understand the growth plasticity and functional diversification of IGFs and GHRs among fish lineages.

\section{Acknowledgements}

This work was supported by Spanish projects (AGL200200551 and AGL2004-06319) from the Ministerio de Educación y Ciencia to Jaume Pérez-Sánchez. Alfonso Saera-Vila was the recipient of a Spanish $\mathrm{PhD}$ fellowship from the Diputación Provincial de Castellón. The authors declare that there is no conflict of interest that would prejudice the impartiality of this scientific work.

\section{References}

Benedet S, Johansson V, Sweeney G, Galay-Burgos M \& Björnsson B 2005 Cloning of two Atlantic salmon growth hormone receptor isoforms and in vitro ligand-binding response. Fish Physiology and Biochemistry 31 315-329.

Benedito-Palos L, Saera-Vila A, Calduch-Giner JA, Kaushik S \& PérezSánchez J 2007 Combined replacement of fish meal and oil in practical diets for fast growing juveniles of gilthead sea bream (Sparus aurata L.): networking of systemic and local components of GH/IGF axis. Aquaculture In Press.

Caelers A, Berishvili G, Meli ML, Eppler E \& Reinecke M 2004 Establishment of a real-time RT-PCR for the determination of absolute amounts of $I G F-I$ and $I G F-I I$ gene expression in liver and extrahepatic sites of the tilapia. General and Comparative Endocrinology 137 196-204.

Calduch-Giner JA, Duval H, Chesnel F, Boeuf G, Pérez-Sánchez J \& Boujard D 2001 Fish growth hormone receptor: molecular characterization of two membrane-anchored forms. Endocrinology 142 3269-3273.

Calduch-Giner JA, Mingarro M, Vega-Rubín de Celis S, Boujard D \& PérezSánchez J 2003 Molecular cloning and characterization of gilthead sea bream (Sparus aurata) growth hormone receptor (GHR). Assessment of alternative splicing. Comparative Biochemistry and Physiology. Part B, Biochemistry and Molecular Biology 136 1-13.

Casse AH, Desplanches D, Mayet-Sornay MH, Raccurt M, Jegou S \& Morel G 2003 Growth hormone receptor expression in atrophying muscle fibers of rats. Endocrinology 144 3692-3697.

Chauvigné F, Gabillard JC, Weil C \& Rescan PY 2003 Effect of refeeding on IGF-I, IGF-II, IGF receptors, FGF2, FGF6, and myostatin mRNA expression in rainbow trout myotomal muscle. General and Comparative Endocrinology 132 209-215.

Chomczynski P \& Sacchi N 1987 Single-step method of RNA isolation by acid guanidinium thiocyanate-phenol-chloroform extraction. Analytical Biochemistry 162 156-159.

Company R, Astola A, Pendón C, Valdivia MM \& Pérez-Sánchez J 2001 Somatotropic regulation of fish growth and adiposity: growth hormone $(\mathrm{GH})$ and somatolactin (SL) relationship. Comparative Biochemistry and Physiology. Part C, Pharmacology and Toxicology 132 435-445.

Denley A, Cosgrove LJ, Booker GW, Wallace JC \& Forbes BE 2005 Molecular interactions of the IGF system. Cytokine and Growth Factor Reviews 16 421-439.
Dickhoff WW, Beckman BR, Larsen DA, Duan C \& Moriyama S 1997 The role of growth in endocrine regulation of salmon smoltification. Fish Physiology and Biochemistry 17 231-236.

Duguay SJ, Lai-Zhang J, Steiner DF, Funkenstein B \& Chan SJ 1996 Developmental and tissue-regulated expression of IGF-I and IGF-II mRNAs in Sparus aurata. Journal of Molecular Endocrinology 16 123-132.

Dyer AR, Barlow CG, Bransden MP, Carter CG, Glencross BD, Richardson N, Thomas PM, Williams KC \& Carragher JF 2004 Correlation of plasma IGF-I concentrations and growth rate in aquacultured finfish: a tool for assessing the potential of new diets. Aquaculture 236 583-592.

Fukada H, Ozaki Y, Pierce AL, Adachi S, Yamauchi K, Hara A, Swanson P \& Dickhoff WW 2004 Salmon growth hormone receptor: molecular cloning, ligand specificity, and response to fasting. General and Comparative Endocrinology 139 61-71.

Fukada H, Ozaki Y, Pierce AL, Adachi S, Yamauchi K, Hara A, Swanson P \& Dickhoff WW 2005 Identification of the salmon somatolactin receptor, a new member of the cytokine receptor family. Endocrinology 146 2354-2361.

Fukamachi S, Yada T \& Mitani H 2005 Medaka receptors for somatolactin and growth hormone: phylogenetic paradox among fish growth hormone receptors. Genetics 171 1875-1883.

Gabillard J-C, Yao K, Vandeputte M, Gutiérrez J \& Le Bail P-Y 2006 Differential expression of two GH receptor mRNAs following temperature change in rainbow trout (Oncorhynchus mykiss). Journal of Endocrinology 190 $29-37$.

Gómez-Requeni P, Mingarro M, Kirchner S, Calduch-Giner JA, Médale F, Corraze G, Panserat S, Martin SAM, Houlihan DF, Kaushik SJ et al. 2003 Effects of dietary amino acid profile on growth performance, key metabolic enzymes and somatotropic axis responsiveness of gilthead sea bream (Sparus aurata). Aquaculture 220 749-767.

Gómez-Requeni P, Mingarro M, Calduch-Giner JA, Médale F, Martin SAM, Houlihan DF, Kaushik S \& Pérez-Sánchez J 2004 Protein growth performance, amino acid utilisation and somatotropic axis responsiveness to fish meal replacement by plant protein sources in gilthead sea bream (Sparus aurata). Aquaculture 232 493-510.

Goodyer CG, Zogopoulos G, Schwartzbauer G, Zheng H, Hendy GN \& Menon RK 2001 Organization and evolution of the human growth hormone receptor gene $5^{\prime}$-flanking region. Endocrinology 142 1923-1934.

Gross P \& Oelgeschläger T 2006 Core promoter-selective RNA polymerase II transcription. Biochemical Society Symposium 225-236.

Hai T \& Hartman MG 2001 The molecular biology and nomenclature of the activating transcription factor/cAMP responsive element binding family of transcription factors: activating transcription factor proteins and homeostasis. Gene 273 1-11.

Jiang H, Okamura CS, Boyd CK \& Lucy MC 2000 Identification of Sp1 as the transcription factor for the alternative promoter $\mathrm{P} 2$ of the bovine growth hormone receptor gene. Journal of Molecular Endocrinology 24 203-214.

Jiao B, Huang X, Chan CB, Zhang L, Wang D \& Cheng CHK 2006 The co-existence of two growth hormone receptors in teleost fish and their differential signal transduction, tissue distribution and hormonal regulation of expression in seabream. Journal of Molecular Endocrinology 36 23-40.

Kajimura S, Kawaguchi N, Kaneko T, Kawazoe I, Hirano T, Visitacion N, Grau EG \& Aida K 2004 Identification of the growth hormone receptor in an advanced teleost, the tilapia (Oreochromis mossambicus) with special reference to its distinct expression pattern in the ovary. Journal of Endocrinology 181 65-76.

Kelly PA, Djiane J, Postel-Vinay MC \& Edery M 1991 The prolactin/growth hormone receptor family. Endocrine Reviews 12 235-251.

Kim HJ, Jung KJ, Yu BP, Cho CG, Choi JS \& Chung HY 2002 Modulation of redox-sensitive transcription factors by calorie restriction during aging. Mechanisms of Ageing and Development 123 1589-1595.

Kim H, Barton E, Muja N, Yakar S, Pennisi P \& LeRoith D 2005 Intact insulin and insulin-like growth factor-I receptor signaling is required for growth hormone effects on skeletal muscle growth and function in vivo. Endocrinology 146 1772-1779.

Kopchick JJ \& Andry JM 2000 Growth hormone (GH), GH receptor, and signal transduction. Molecular Genetics and Metabolism 71 293-314.

Larsen DA, Beckman BR \& Dickhoff WW 2001 The effect of low temperature and fasting during the winter on metabolic stores and 
endocrine physiology (insulin, insulin-like growth factor-I, and thyroxine) of coho salmon, Oncorhynchus kisutch. General and Comparative Endocrinology 123 308-323.

Lee LTO, Nong G, Chan YH, Tse DLY \& Cheng CHK 2001 Molecular cloning of a teleost growth hormone receptor and its functional interaction with human growth hormone. Gene 270 121-129.

Li MH, Peterson BC, Janes CL \& Robinson EH 2006 Comparison of diets containing various fish meal levels on growth performance, body composition, and insulin-like growth factor-I of juvenile channel catfish Ictalurus punctatus of different strains. Aquaculture 253 628-635.

Livak KJ \& Schmittgen TD 2001 Analysis of relative gene expression data using real-time quantitative PCR and the $2^{-\Delta \Delta C}$ T method. Methods 25 402-408.

Mantovani R 1999 The molecular biology of the CCAAT-binding factor NF-Y. Gene 239 15-27.

Martínez-Barberá JP, Pendón C, Martí-Palanca H, Calduch-Giner JA, Rodríguez RB, Valdivia MM \& Pérez-Sánchez J 1995 The use of recombinant gilthead sea bream (Sparus aurata) growth hormone for radioiodination and standard preparation in radioimmunoassay. Comparative Biochemistry and Physiology. Part A, Molecular \& Integrative Physiology 110 335-340.

Mingarro M, Vega-Rubín de Celis S, Astola A, Pendón C, Martínez Valdivia M \& Pérez-Sánchez J 2002 Endocrine mediators of seasonal growth in gilthead sea bream (Sparus aurata): the growth hormone and somatolactin paradigm. General and Comparative Endocrinology 128 102-111.

Moerth C, Schneider MR, Renner-Mueller I, Blutke A, Elmlinger MW, Erben RG, Camacho-Hübner C, Hoeflich A \& Wolf E 2007 Postnatally elevated levels of insulin-like growth factor (IGF)-II Fail to rescue the dwarfism of IGF-I-deficient mice except kidney weight. Endocrinology 148 441-451.

Nakao N, Higashimoto Y, Ohkubo T, Yoshizato H, Nakai N, Nakashima K \& Tanaka M 2004 Characterization of structure and expression of the growth hormone receptor gene of the Japanese flounder (Paralichtys olivaceus). Journal of Endocrinology 182 157-164.

Nordgarden U, Hansen T, Hemre GI, Sundby A \& Björnsson BT 2005 Endocrine growth regulation of adult Atlantic salmon in seawater: the effects of light regime on plasma growth hormone, insulin-like growth factor-I, and insulin levels. Aquaculture 250 862-871.

Orlovskii IV, Sverdlova PS \& Rubtsov PM 2004 Fine structure, expression, and polymorphism of the human growth hormone receptor gene. Molecular Biology 38 24-33.

Ozaki Y, Fukada H, Kazeto Y, Adachi S, Hara A \& Yamauchi K 2006 Molecular cloning and characterization of growth hormone receptor and its homologue in the Japanese eel (Anguilla japonica). Comparative Biochemistry and Physiology. Part B, Biochemistry and Molecular Biology 143 422-431.

Pérez-Sánchez J, Calduch-Giner JA, Mingarro M, Vega-Rubín de Celis S, Gómez-Requeni P, Saera-Vila A, Astola A \& Valdivia MM 2002 Overview of fish growth hormone family. New insights in genomic organization and heterogeneity of growth hormone receptors. Fish Physiology and Biochemistry 27 243-258.

Peterson BC, Waldbieser GC \& Bilodeau L 2004 IGF-I and IGF-II mRNA expression in slow and fast growing families of USDA103 channel catfish (Ictalurus punctatus). Comparative Biochemistry and Physiology. Part A. Molecular and Integrative Physiology 139 317-323.

Prabhakar NR 2001 Physiological and genomic consequences of intermittent hypoxia: invited review: oxygen sensing during intermittent hypoxia: cellular and molecular mechanisms. Journal of Applied Physiology 90 1986-1994.

Le Roith D, Bondy C, Yakar S, Liu JL \& Butler A 2001a The somatomedin hypothesis: 2001. Endocrine Reviews 22 53-74.

Le Roith D, Scavo L \& Butler A $2001 b$ What is the role of circulating IGF-I? Trends in Endocrinology and Metabolism 12 48-52.

Rotwein P 1991 Structure, evolution, expression and regulation of insulinlike growth factors I and II. Growth Factors 5 3-18.
Saera-Vila A, Calduch-Giner JA \& Pérez-Sánchez J 2005 Duplication of growth hormone receptor (GHR) in fish genome: gene organization and transcriptional regulation of GHR type I and II in gilthead sea bream (Sparus aurata). General and Comparative Endocrinology 142 193-203.

Silverstein JT, Wolters WR, Shimizu M \& Dickhoff WW 2000 Bovine growth hormone treatment of channel catfish: strain and temperature effects on growth, plasma IGF-I levels, feed intake and efficiency and body composition. Aquaculture 190 77-88.

Smale ST 1997 Transcription initiation from TATA-less promoters within eukaryotic protein-coding genes. Biochimica et Biophysica Acta 1351 73-88.

Smale ST \& Kadonaga JT 2003 The RNA polymerase II core promoter. Annual Review of Biochemistry 72 449-479.

Tse DLY, Tse MCL, Chan CB, Deng L, Zhang WM, Lin HR \& Cheng CHK 2003 Seabream growth hormone receptor: molecular cloning and functional studies of the full-length cDNA, and tissue expression of two alternatively spliced forms. Biochimica et Biophysica Acta 1625 64-76.

Tsujimoto K, Ono T, Sato M, Nishida T, Oguma T \& Tadakuma T 2005 Regulation of the expression of caspase- 9 by the transcription factor activator protein-4 in glucocorticoid-induced apoptosis. Journal of Biological Chemistry $28027638-27644$.

Vega-Rubín de Celis S, Gómez P, Calduch-Giner JA, Médale F \& PérezSánchez J 2003 Expression and characterization of european sea bass (Dicentrarchus labrax) somatolactin: assessment of in vivo metabolic effects. Marine Biotechnology 5 92-101.

Vega-Rubín de Celis S, Gómez-Requeni P \& Pérez-Sánchez J 2004a Production and characterization of recombinantly derived peptides and antibodies for accurate determinations of somatolactin, growth hormone and insulin-like growth factor-I in European sea bass (Dicentrarchus labrax). General and Comparative Endocrinology 139 266-277.

Vega-Rubín de Celis S, Rojas P, Gómez-Requeni P, Albalat A, Gutiérrez J, Médale F, Kaushik SJ, Navarro I \& Pérez-Sánchez J 2004b Nutritional assessment of somatolactin function in gilthead sea bream (Sparus aurata): concurrent changes in somatotropic axis and pancreatic hormones. Comparative Biochemistry and Physiology. Part A, Molecular and Integrative Physiology 138 533-542.

Very NM, Kittilson JD, Norbeck LA \& Sheridan MA 2005 Isolation, characterization, and distribution of two cDNAs encoding for growth hormone receptor in rainbow trout (Oncorhynchus mykiss). Comparative Biochemistry and Physiology. Part B, Biochemistry and Molecular Biology 140 615-628.

Volff JN 2005 Genome evolution and biodiversity in teleost fish. Heredity 94 280-294.

Vong QP, Chan KM \& Cheng CH 2003 Quantification of common carp (Cyprinus carpio) IGF-I and IGF-II mRNA by real-time PCR: differential regulation of expression by GH. Journal of Endocrinology 178 513-521.

Wei Y, Rhani Z \& Goodyer CG 2006 Characterization of growth hormone receptor messenger ribonucleic acid variants in human adipocytes. Journal of Clinical Endocrinology and Metabolism 91 1901-1908.

Wood AW, Duan C \& Bern HA 2005 Insulin-like growth factor signaling in fish. In International Review of Cytology, Ed K W Joan vol 243. New York: Academic Press, pp 215-285.

Xu Q, Springer L, Merchant JL \& Jiang H 2006 Identification of zinc finger binding protein 89 (ZBP-89) as a transcriptional activator for a major bovine growth hormone receptor promoter. Molecular and Cellular Endocrinology 251 88-95.

Zhou R, Cheng H \& Tiersch TR 2001 Differential genome duplication and fish diversity. Reviews in Fish Biology and Fisheries 11 331-337.

Received in final form 18 May 2007

Accepted 21 May 2007

Made available online as an Accepted Preprint 21 May 2007 